\title{
Development Time Signal Violation Learning Video for Basic Basketball Referee
}

\author{
Raditya Pratama $^{1}$, Himawan Wismanadi ${ }^{2}$, Abdul Rachman Syam Tuasikal ${ }^{3}$ \\ ${ }_{1,2,3}$ Magister of Physical Education, Universitas Negeri Surabaya, Indonesia \\ raditya.17070805042@mhs.unesa.ac.id
}

\begin{abstract}
Time signal violation material is a basic material that must be mastered by a basketball referee. This research includes the type of research and development. The results of this research and development is a learning tool basketball refereeing time signal violation tool packed in a dvd video. Results of small group testing of the product obtained a feasibility percentage of $83.33 \%$. While the results of large group trials obtained a percentage of eligibility of $88.97 \%$.
\end{abstract}

Keywords: Learning; referee; time signal violation.

\section{Introduction}

To achieve a healthy life physically and spiritually can be done in various ways, one of them is to do sports activities. Sport is an activity to train one's body to be fit. Exercise is proven to improve one's health and physical fitness level.

Currently the Indonesian people are talking a lot about basketball. Basketball is a combination of several individual and team techniques that come together in an overall collaboration. Basically basketball is a very fast and dynamic game. Basketball games are not much different from sports games in general, need power, energy, mentally, and strategy. However, there are fundamental differences in game patterns, defense patterns, and game rules.

Along with the development of basketball in Indonesia, especially in East Java, there is one role that is very helpful in the development of basketball, this role is taken by a referee, the referee is also required to improve the quality of the individual, knowledge of rules, performance on the field and knowledge of how to interpret a basketball rule where the referee is a court judge.

The referee is a very important supporting element in a basketball game. A match can not be separated from the role of the referee. The match will not run if there is no referee. The referee is the most important part of a match, because the referee is tasked to guide and oversee the match from beginning to end in accordance with applicable regulations, besides the referee also served as an intermediary and the court if there are things that are not in accordance with the regulations, then these things will be returned in accordance with applicable regulations.

Referees in basketball must have accuracy, speed of reaction, accuracy in making decisions without hesitation based on rules and interpretation of appropriate actions. In this case the referee must understand and know what is needed, prepared, and must be done before, during, and after the game because basketball sports are dynamic, active, and with fast movements that are played in a limited space so that the intersection is very possible in this sport. With the intersection that occurs is expected not to affect the course of the match, for it is made rules that are adjusted and to keep things that are not desirable that can interfere with sportsmanship.

If in a match the start from the beginning to the end goes well, all decisions taken by the referee are all correct, but at the end of the match that only takes a few seconds, such as the last 8 seconds, a referee suddenly made a mistake in making a decision and it can affect the outcome of the match, then the referee's mistake will be a bad memory for the referee 
himself, the coach, the player, or the organizing committee because of the possibility of a match from the start went well but in the end something went wrong and this makes the referee feel guilty until whenever and this will be able to affect the appearance of the referee in every lead of a match.

Examples of cases that often occur that can result in coaches being dissatisfied with a referee's leadership are a time violation, because in a basketball game there are several violations related to time, there are about 3 seconds, 5 seconds, 8 seconds, 14 seconds and 24 seconds. 3 second violations are usually asked by a player and even a coach, they ask why the violations did not occur, because obviously an opposing player is in the key hole area for 3 seconds even more. Next 5 second violations, these violations are of 2 types namely violations that are inside the field and outside the field. Further more, the 14 second violation, in the case of this violation is quite difficult to identify, this is considered difficult because it requires some accuracy in seeing the state of the ball already or has not touched the ring, the ball is in new possession in the frontcourt or in the backcourt.

This last offense is most often cant accept by a coach, a player, even all sets of matches. The audience can also judge if this violation occurs, such as the atmosphere where the match was initially silent can be instantly noisy and protests and support voices emerge. Commonly called a 24 second offense, this offense is a concern because it can change a match result, this is caused by the accuracy factor of a referee to see the state of the ball and time, which event first occurs, whether the ball first enters the basket, whether this 24 second violation is created.

To avoid this, the referee must prepare as well as possible, learn about the limits of what is a violation of time. According to the national level refereeing curriculum for $\mathrm{C}$-level basketball ball (2012), referee education at C-level or elementary level is initial education that addresses important points referring to FIBA rule, the discussion must be discussed in detail and in depth. The basic rules in FIBA must be thoroughly discussed in the upgrading, because the aim of the $\mathrm{C}$ level upgrading, participants who are declared to pass will have the knowledge and skills to referee a basic level basketball and can lead the elementary, middle, high school and equivalent level matches..

Actually, the research about basketball referees is not new, because research on basketball basketball referees, was developed by sister Dina Charisma Ganda in 2012 which examined into the form of a pocket book aimed at helping the learning process of one of the materials in the second basketball course II, Imam Arief Efendi in 2014 who developed a learning media for mobile learning-based basketball referee signals for theoretical and practical subjects II State University of Malang, Byan Candra Gloria Estefan in 2014 who developed animation animation for basketball training for learning in physical education, sports and health for class XII Brawijaya Senior High School Malang and Hendro Widianto in 2015 who developed learning media for mobile learning scabesheet based on learning learning for basketball class II in the majors of Brawijaya Smart School Malang and Hendro Widianto in 2015 who developed learning media for mobile learning based on learning for basketball. Physical Education and Health Malang State University. Seeing from the research that has been developed above, that the development of research is only based on mobile learning and book media, from here researchers see an opportunity, that in learning to be a media referee is not enough to learn, in this case the researcher intends to develop existing findings into products that have never been done. 
Seeing the results of research that have been examined and see the problems that often occur, in this case is about time violations, here comes the idea of thinking to create a learning medium that discusses about time violations. Starting from violations of 3 second, 5 second, 8 second, 14 second, and 24 second referee at the basic level must understand what limits are a time violation. Wasit sendiri harus dapat meyakinkan para perangkat pertandingan terutama pemain dan pelatih, bahwa hasil keputusan yang diambil oleh seorang wasit adalah benar dan tidak memihak. Maka dengan permasalahan diatas terbentuk ide membuat media pembelajaran dengan judul "Development of Time Signal Violation Learning Video for Basic Basketball Referee“.

\section{Review of Literature}

Sodikun (1992, p. 8) basketball is a sport played by two teams, each team consisting of 5 players each, each team is forced to force the ball into the ring and collect as many points as possible. The first named team uses the bright team shirt (always white) and the second named uses the dark team shirt (all colors except white). The duration of the game in basketball 4 x 10 minutes. In a basketball game, the match is led by 3 referees, while the related match equipment is in the form of a table clerk and match supervisor, the number of desk clerks totaling 4 people and the number of match supervisors totaling 1 person. Other match sets are timer, shot clock, match supervisor, score taker, and assistant score.

Wissel $(2008$, p. 2), the goal of playing basketball is to get a score by entering the opponent's basket ball and preventing the opposing team from doing the same thing. Oliver (2007, p. 6) states "basketball is one of the most popular sports in the world. Fans of all ages feel that basketball is a fun, competitive sport, educating entertaining and healthy ". This opinion is supported by PB Perbasi (2010, p. 1), a basketball game played by two (2) teams, each consisting of five (5) players. The goal of each team is to score the opponent's basket and try to prevent the opposing team from scoring. The match is controlled by the referee, the desk clerk and a commissioner, if present.

Based on the above it can be concluded that, basketball game is a group or team game, each of which consists of 12 players including the captain, who are in the field as many as five players each team with the aim is to score numbers into the opponent's basket as much as and prevent opponents from scoring as many as possible into our basket, basketball playing is done by passing, dribbling, and not only that, the strength of the endurance of each player and teamwork very influential in a basketball game. In accordance with the expert opinion above the basketball game is not only fun and healthy, but there is also a competitive and entertainment. In addition, every player who plays a basketball game is required to always play fair play, and be responsible.

Dimyati and Mudjiono (2009, p. 7) which suggests that learning is a preparation prepared by the teacher to attract and provide information to students, so that with good preparation and well designed by the teacher the teacher will assist students in facing the goals to be achieved. The term of learning is related to understanding learning and teaching. Learning, teaching and learning occur simultaneously. Learning can occur without a teacher or without other formal teaching and learning activities. While teaching includes everything that teachers do inside and outside the classroom. In the sense of Indonesian learning can be interpreted as a process or a way to make people or creatures learn. In addition to the above 
understanding, there are some experts who express the meaning of learning. The word "learning" is a translation of the word "instruction", which is widely used in education in the United States. According to the UM Education Guidelines (2011, p. 20) "learning is an active-interactive activity of students with a learning environment instructed by educators. According to Setyosari and Sihkabuden $(2005$, p. 17) "learning or teaching is an effort to learn students".

Sumiati (2007, p. 3) states "learning is essentially a complex process (complicated), but with the same purpose, namely to provide learning experiences to students in accordance with the objectives". Rusman (2011, p. 15) also argues "learning is a process of creating conditions conducive to teaching and learning communication interactions between instructors, students, and other learning components to achieve learning goals". Based on these opinions it can be concluded that, learning is an interaction between teachers and students so that students have something new, which they can from experience, both in terms of knowledge, skills, and attitudes.

Rosdiana (2012, p. 1) states "learning is how to do things and helps students to understand declarative knowledge, that is knowledge about something". In essence, learning is a process of interaction between teachers and students, both direct and indirect interactions. The essence of learning is a bond of interaction between teachers to students in order to get something new, both in terms of cognitive, affective and psychomotor so that students get something new from the results of their experiences, this can be obtained by someone from the formal and non-formal education environment. As we all know that learning is an aspect that can not be avoided, because basically humans have learned since he was born without having any restrictions, such as gender, age and even time.

According to Setyosari and Sihkabuden (2005, p. 16) "Learning media is a tool or means or device that functions as an intermediary or bridge channel in communication activities between communicators (messenger) and communicants (recipients of messages)". According to Dwiyogo (2010, p. 229) "Media is a tool or method used as an intermediary to convey information (messages) in order to be fully accepted by recipients of information". Meanwhile according to Sadiman et al. (2011, p. 7) namely "Media is everything that can be used to channel messages from the sender to the recipient so that it can stimulate the thoughts, feelings, concerns and interests and attention of students in such a way that the learning process occurs". From some of the above media meanings it can be concluded that the media is a tool used or functions as an intermediary to convey messages or information.

From the understanding of media and learning according to the experts above it can be concluded that learning media is a medium used for teaching and learning activities so that the interaction and communication of educators and students can take place effectively and efficiently which can stimulate student interest in learning to achieve learning goals. This is in accordance with Dwiyogo (2010, p. 229) which states "something is said as a medium of learning if the media is used to convey messages with educational and learning goals".

Every educator in delivering learning material must think about the learning media that will be used, because the use of appropriate learning media plays an important role to stimulate students' activeness interests in order to achieve learning goals. According to Dwiyogo (2010, p. 230) the use of instructional media in the learning process, functions as follows: 
Learning media attracts and enlarges students' attention to the teaching material presented, (b) Learning media addresses differences in learning experiences based on socioeconomic backgrounds of students, (c) Learning media helps provide learning experiences that are difficult to obtain in other ways, (d ) Learning media can foster the ability to work on their own based on experience and reality, (e) By using instructional media appropriately and varied it can be overcome passive attitudes of students, (f) Learning media can cause excitement to learn, (g) Learning media allows more interaction directly between students with the environment and reality, (h) Learning media allows students to learn themselves according to their abilities and interests.

Based on the opinions of some of the experts above, it can be concluded that the learning media functions as a real and direct intermediary in the delivery of information or material that is attractively packaged so as to generate interest or motivation for students' learning. The development of instructional media in the form of learning videos for basketball referee signals is expected to be able to attract the interest of Malang basketball referees to understand the basketball referee signal when competed or not in a match as a form of increasing the referee's performance.

According to Riyana (2007, p. 1) instructional video media is a medium that presents audio and visuals containing good learning messages that contain concepts, principles, procedures, theories of application of knowledge to help understanding of a learning material. Video is an audio visual learning material that can be used to convey messages or subject matter. Said to be heard because the elements can be heard (audio) and said to appear because the elements can be seen (video) can be presented together. Video is learning material that is packaged through a video tape and can be viewed through a video / VCD player that is connected to a television monitor (Sungkono, 2003, p. 65).

According to Riyana (2007, p. 8-11) to produce a learning video that can increase the motivation and effectiveness of its users, the development of learning videos must pay attention to the characters and criteria. The learning video character is:

a. Clarity of message, with instructional video media can understand learning messages more meaningfully and information can be received in full so that automatically the information will be stored in long-term memory.

b. Stand alone, the video developed does not depend on other teaching materials or does not have to be used together with other teaching materials.

c. Friendly, learning video media use language that is simple, easy to understand, and uses common language. Display information that appears to be helpful and friendly with the wearer, including the ease of users in responding as desired.

d. Content representation, material must be truly representation, for example simulation or demonstration material. Basically the material, both social and scientific, can be made into video media.

e. Visualization with the media, the material is packed in a multimedia contained in it text, animation, sound, and video according to the material. The materials used are applicative, process able, difficult to reach, dangerous if directly practiced, have high accuracy.

f. Using high resolution quality, the display in the form of graphic video media is made with digital engineering technology with high resolution but support for every computer system spech. 
g. Can be used classically or individually, learning videos can be used by students individually, not only in school settings, but can also be used at home. Can also be used classically with up to 50 people guided by the teacher or simply listen to the description.

The advantage of using instructional video media according to Daryanto (2010, p. 90) video display size is very flexible and can be arranged as needed, video is a non-printed teaching material that is rich in information and straightforward because it can reach the user directly and the video adds a new dimension towards learning.

According to Riyana (2007, p. 11-14) the development and making of learning videos must consider the following criteria:

a. Material, learning video media for subject matter that is describing a particular process, a demonstration plot, a concept or describing something. For example how to make the right cake and others.

b. Duration of time, video media has a shorter duration of about 20-40 minutes, in contrast to films which generally have a duration of 2-3.5 hours. Considering the ability of memory and the ability to concentrate in humans is quite limited between 15-20 minutes, making video media able to give advantages compared to film.

c. Video presentation formats, films are generally presented with a format of dialogue with more dramatic elements. Freelance films are imaginative and less scientific. This is different from the presentation requirements for learning videos that prioritize clarity and mastery of the material. Video formats suitable for learning include: narrative (narrator), interviews, presenters, and a combined format.

d. Technical provisions, according to Riyana (2007, p. 13) video media can not be separated from the technical aspects of the camera, shooting techniques, lighting techniques, editing and sound. Learning emphasizes more on message clarity, thus communicative offerings need technical support such as using zoom in and zoom out techniques, selection of text and proportional text size, correct combination of object settings and using in focus and out focus techniques.

e. The use of music and sound effects, several provisions of music and sound effects according to Riyana (2007, p. 14):

a) Music for sound accompaniment should be with a low volume intensity, so it does not interfere with visual presentation and narrator.

b) Music used as a background should be musical instruments.

c) Avoid music with songs that are popular or familiar.

d) Use sound effects to add atmosphere and complete visual presentations and add a better impression.

It can be concluded that with the addition of music in video media will be able to attract the attention of people who see in listening to the material provided.

FIBA Rules (2018) the referee is the court judge on the court. The referee has full rights during the game to all players and the coach and official of a team. The role of the referee is very important for the sake of regular competition. Each referee has the authority to make decisions within the limits of his duties, but does not have the authority to ignore or oppose decisions that have been made by other referees.

Pedowitz (2008) says there are several elements that influence the character of a referee including: 
Referee-specific characteristics include (1) age, (2) years of NBA officiating experience, (3) whether the referee played varsity-level college basketball, (4) whether the referee earned an undergraduate degree, (5) whether the referee earned a graduate degree, and (6) race. In addition, we include measures of referee quality. The NBA keeps its own internal ratings of referees and uses a proprietary statistical evaluation tool to determine which most highly qualified officials will work the play-offs

From the explanation above, the character of a basketball referee can be judged by looking at the age, how many years of being a referee, the level of education and the results of the evaluation of each match intended to produce a basketball referee who is ready to work in all matches.

According to Robert S. Weinberg (2013), being a referee is not only technical knowledge and understanding of the regulations needed, but many other elements needed include elements of art and the referee's personal qualities themselves. The abilities that must be possessed by a referee are: 1) consistency, 2) relationship (cooperation), 3) firmness, 4) calmness, 5) integrity, 6) decision, 7) trust, 8) motivation.

\section{Research Methods}

This research and development method uses a procedural model. According to the Guidelines for Writing Scientific Papers (2010, p. 46) "The procedural model is a descriptive model, which outlines the steps that must be followed to produce a product". This research and development on time signal violation for basketball referees refers to the Research \& Development (R\&D) development model of Borg \& Gall (1983, p. 775) consisting of ten steps. Each developer can of course choose and determine the steps that are most appropriate for him based on the specific conditions faced in the development process (Ardhana, 2002, p. 9). Researchers do not use all the steps of the Borg and Gall development model, but only use seven steps due to limited time, energy, and cost and are adjusted to the characteristics of the product to be developed.

The design of the development of time signal violation learning media for basketball referees consists of: (1) needs analysis, (2) making an initial product that is, the initial product of learning time video violation learning media for basketball referees, (3) expert evaluation, (4) product revisions, (5) small group trials, (6) large group trials, and (7) final results of the development of learning media for time signal violation learning videos for basketball referees.

The type of data obtained is qualitative and quantitative. Qualitative data were obtained from the results of expert reviews in the form of input, suggestions, and evaluations. While quantitative data were obtained from needs analysis, trial I (small group) and trial II (large group).

Data collection instruments used in this study were questionnaires. The questionnaire was used to collect quantitative data, including needs analysis, expert evaluation, trial I (small group), and trial II (large group). 


\section{Discussion}

\subsection{Results}

In the results of this research and development will be presented needs analysis data obtained from the distribution of questionnaires to 37 Malang City basketball referees. It will also be presented data on the results of evaluation of media experts, evaluation results of learning experts, results of evaluation of basketball experts, small group trial results, and results of large group trials. Small group trials using research subjects as many as 6 basic level basketball referees in Malang City, while large group trials using research subjects as many as 31 Malang City basketball referees. Data from small group and large group trial results were obtained from the answers of Malang City basketball referees as subjects, using the method of data collection in the form of instruments in the form of questionnaires. Data from the expert evaluation results were also obtained from expert answers to the questionnaire given.

In the development of time signal violation learning videos for elementary level basketball referees in Malang, the technique used to process data is the percentage technique. The result data presented is the result data from the evaluation of learning media experts, the results of the evaluation of basketball learning experts, the results of evaluation of basketball experts, the results of small group trials, and the results of large group trials.

In the results of this development, needs analysis data were obtained from 37 basketball referees in Malang. The data was obtained using a questionnaire that was distributed to Malang City basketball referees. Then the result data is obtained by seeing the answers of 37 basketball referees.

From the results of the evaluation of media experts, it was obtained $100 \%$ so that it can be concluded that the learning media in the form of video learning time signal violation for basketball referees is already good, but there are still shortcomings of the results of the development in order to become more interesting and achieve learning objectives through the developed media. From the results of the evaluation, the media experts obtained suggestions and input that reforms by adding an introduction to the beginning of the video.

From the evaluation results of learning experts obtained $100 \%$ results so that it can be concluded that the scope of the material is very complete and suitable for use as a learning medium by basketball referees. From the results of the evaluation, the learning expert gets advice and input that an introductory opener must be given, the video is given an identifier and whoever has a role in making the video at the end of the video, and provides information to explain the video.

From the results of the evaluation of the basketball team experts the results are $100 \%$ so it can be concluded that the material presented is very appropriate and easy to understand. From the results of the evaluation the basketball team expert obtained advice and input that the lack of explanation regarding the regulation of time signal violation.

Trial I (small group) was conducted on Sunday, April 25, 20119. From the results of the evaluation of the phase I trial (small group, $n=6$ ) a percentage of $83.33 \%$ was obtained so that the time signal violation learning video product for the basketball referee as a whole was quite interesting, obviously, it is very suitable to help basketball referees, it is easy and useful to improve basketball referee performance. However, there is a lack of introduction of whose product it belongs to and lack of clarity of information. Therefore, based on these 
results, the learning media in the form of learning videos need to be revised again so that they can be used as learning media for basketball referees in the form of learning videos for basketball referee participants.

Trial II (large group) was conducted on Sunday, May 20, 2019. From the results of the phase II trial evaluation (large group, $\mathrm{n}=31$ ) a percentage of $88.97 \%$ was obtained so that the time signal violation learning video product developed was very clear, the overall appearance very interesting, easy to use, and appropriate when used as a video medium for learning time signal violation for basketball referees.

Based on data collected from the results of expert evaluations, small group trials, and large group trials conducted, the product development time video violation learning for basic basketball referees in the city of Malang, there are several parts of the product that need to be revised. Product revision based on input and findings obtained during expert evaluation, small group and large group trials are intended to make the product developed better and is suitable for use.

The following are suggestions from media experts on the results of the initial product design development of time signal violation learning videos for Malang elementary level basketball referees, among others: (1) there must be an opening for identification as a product identity, (2) deletion of several words so that the title looks interesting and clear.

Further more, the learning expert also gave some suggestions on the results of the initial product design development of time signal violation learning videos for basketball referees at the basic level, including: (1) an identification cover at the beginning of the video opener, (2) giving information when the time regulation began, (3) credit credit is given at the end of the video as a description of the researchers' personal data and anyone who has a role to assist in the video making process.

In addition to advice from media experts and learning experts, basketball experts also provide advice on the initial product design in the form of the need to provide an explanation to further explain the rules of time, this is because learning video products are not only useful for basketball referees, but there is great hope for the product This learning video can be useful for sports students and other students who want to be involved as umpires.

After a revision of the experts' recommendations, the researchers proceeded to the next step, the product trial, which was carried out in two stages, the first stage was a small group trial, where in this group test a 83.33\% result was obtained for 6 basketball referees. the basic level of Malang City and this media are included in the quite valid category. However, there are deficiencies in the provision of information to the rules explained. After that, the researchers revised and proceeded to the next stage, which was a large group trial field test, and obtained a result of $88.97 \%$ of 31 Malang City basketball referees and video time learning violation media for the basketball referee was very interesting, very understandable, very suitable to help the basketball referee performance, it is very feasible and very complete if this time signal violation learning video is used for participants of the Malang basketball referee.

\subsection{Discussion}

The final product of this research and development is a time signal violation learning video for the elementary basketball referee in Malang. According to Riyana (2007) instructional video media is a medium that presents audio and visuals that contain learning 
messages that contain concepts, principles, procedures, theories of application of knowledge to help the understanding of a learning material.

Video is an audio visual learning material that can be used to convey messages or subject matter. Said to be heard because the elements can be heard (audio) and said to appear because the elements can be seen (video) can be presented together.

According to Riyana (2007, p. 8-11) to produce a learning video that can increase the motivation and effectiveness of its users, the development of learning videos must pay attention to the characters and criteria, the learning video characters including the clarity of the message, with instructional video media can understand the learning message as more meaningful and information can be received in its entirety so that by itself the information will be stored in long-term memory, after the learning video has a message, videos must also be able to stand alone, in the sense that they do not have to be used with other materials together, then, learning videos are also friendly to users, using simple language, easy to understand, using common language, and exposure to information displayed is helpful the user, including making it easier for users to respond according to the contents of the material in the video must be truly a representation, for example, there is good simulation and demonstration material, in addition to the content of the material that is represented, the material also needs to be packaged with multimedia in which there is text, animation, sound and video accordingly. Video quality must also be of high resolution as well as with graphics created with digital engineering technology but still must support for each computer system spech, can be used classically or individually, learning videos can be used by students individually, not only in school settings, but can also be used at home. Can also be used classically with up to 50 people guided by the teacher or simply listen to the description.

Daryanto (2010, p. 90) video display size is very flexible and can be arranged as needed, video is a non-printed teaching material that is rich in information and straightforward because it can reach the user directly and the video adds a new dimension to learning. In making learning videos using the DVD format, why DVD because this media has advantages in accordance with the expectations of researchers. Image clarity becomes the main factor, because image clarity is very important in a learning video media, besides that DVD has a larger space that is able to play longer shows.

In addition to the advantages above the time signal violation learning video for the basketball referee is high resolution, with the hope that the image quality is clear, the basketball referee can understand the time signal violation correctly. Time refraction time signal violation learning video has been equipped with 3-dimensional animation that matches the events in the field according to the latest regulations FIBA 2018. The advantage of the next time signal violation learning video product is the description of the written animation, which makes this learning video interesting, and is supported by dubber is increasingly making this video learning time signal violation basketball referee more easily understood.

From the advantages that have been outlined above, this product also has some disadvantages including, this product has a high image resolution so it requires a large capacity storage space. This product also uses simple 3-dimensional animation and this learning video has not used attractive written animation. 


\section{Conclusion}

It can be concluded that the video learning time signal violation for the basketball referee in the elementary level can be used to achieve the learning objectives that is able to understand and be able to practice the time signal violation of the basketball referee as an independent learning media that can be used anywhere and anytime.

The development of time signal violation learning videos for basic basketball referees can help basketball referees understand the concept of time signals violation for basketball referees and can implement the concept of learning time signal violations into practice in the field. The resulting product is a product intended for basic level basketball referees, but this does not exclude the possibility that this product can be used by other parties who want to learn about basketball referees..

In disseminating development products to a broader target, researchers provide advice that is socialized to related parties, such as PERBASI administrators especially in the field of arbitration, lecturers supporting basketball subjects, so that this product receives recognition as a video learning time signal violation for basketball referees that deserves to be disseminated, but before disseminating this product should be reorganized for the better.

Researcher's suggestions in the development of this research towards further, as follows, (a) We recommend that the video learning time signal violation ball basketball referee developed not only be used by Malang City basketball referees, but can also be used by other parties who want to be involved in world of basketball referee. (b) Video learning time signal violation of the basketball referee is necessary to review the development of the basketball which from year to year is always undergoing an update. (c) Further research should be carried out to determine the effectiveness of the product being developed, because the results of this development are still limited until the compilation of a product. Similarly, suggestions for the use, dissemination and further development of products for the development of time signal violation learning videos for basic basketball referees.

\section{References}

AHSAA. (2016). Basketball Official Manual. Alabama High School Atletic Association. Alabama

Akbar, S and Sriwiyana, H. (2010). Pengembangan Kurikulum dan Pembelajaran Ilmu Pengetahuan Sosial (IPS). Yogyakarta: Cipta Media.

Ardhana, W. (2002). Metodologi Penelitian Pengembangan Bidang Pendidikan dan Pembelajaran. Makalah disajikan dalam Lokakarya Nasional Angkatan II, Jurusan Ilmu Keolahragaan UM, Malang, 22 Maret.

Arikunto, S. (1997). Prosedur Penelitian Suatu Pendekatan Praktek. Jakarta: Rineka Cipta

Borg, W.R. and Gall, M.D. (1983). Educational Research An Introduction. New York \& London: Longman.

Cheppy Riyana. (2007). Pedoman Pengembangan Media Video. Jakarta: P3AI UPI

Daryanto. (2010). Media Pembelajaran, Peranannya Sangat Penting Dalam Mencapai Tujuan Pembelajaran. Yogyakarta: Gava Media.

Dimyati and Mudjiono. (2006). Belajar dan Pembelajaran. Jakarta: Rineka Cipta 
Dwiyogo, Wasis D. (2008). Aplikasi Teknologi Pembelajaran Media Pembelajaran Penjas \& Olahraga. Malang: Departemen Pendidikan Nasional Universitas Negeri Malang.

Dwiyogo, Wasis D. (2010). Dimensi Teknologi Pembelajaran Pendidikan Jasmani dan Olahraga. Malang: Wineka Media.

FIBA. (2014). Official Basketball Rules. Puerto Rico, San Juan: FIBA Central Board.

FIBA. (2010). Official Basketball Rules Ofiicial Interpretation. Puerto Rico, San Juan: FIBA Central Board.

FIBA. (2014). Official Basketball Rules Ofiicial Interpretation. Puerto Rico, San Juan: FIBA Central Board.

FIBA. (2010). 3 Person Officiating Basic Update. Puerto Rico, San Juan: FIBA Central Board.

FIBA. (2014). 3 Person Officiating Basic Update. Puerto Rico, San Juan: FIBA Central Board.

FIBA. (2015). 3 Person Officiating Basic Update. Puerto Rico, San Juan: FIBA Central Board.

Gift, P and Ryan M. R. (2014). Napoleon Complex : Height Bias Among National Basketball Association Referees. Journal Of Sport Economics : 4

Leicht, A. S. (2008). Physiological Demands of Basketball Refereeing During International Competition. Journal of Science and Medicine in Sport 11 : 357 - 358

Oliver, John. (2007). Dasar-dasar Bolabasket. Bandung: Pakar Katya.

PERBASI. (2010). Buku Peraturan Resmi Bolabasket. Jakarta: PERBASI

Sadiman, A. et al. (2003). Media Pendidikan Pengertian, Pengembangan dan Pemanfaatannya. Jakarta: RajaGrafindo Persada.

Sadiman, A,et al. (2010). Media Pendidikan Pengertian, Pengembangan, dan Pemanfaatannya. Jakarta: RajaGrafindo Persada.

Sodikun. (1991). Olahraga Bola Basket. Jakarta: Depdikbud

SEAMOLEC. (2013). Pembuatan Buku Digital. SEAMOLEC

Setyosari and Sihkabuden. (2005). Media Pembelajaran. Malang: Elang Mas.

Sugiyono. (2012). Metode Penelitian Kuantitatif, Kualitatif dan $R$ \& D. Bandung: Alfabeta

Universitas Negeri Malang. (2010). Pedoman Penulisan Karya Ilmiah. Edisi kelima. Malang:

Biro Administrasi Akademik, Perencanaan dan Sistem Informasi bekerjasama dengan

Penerbit Universitas Negeri Malang.

Universitas Negeri Malang. (2011). Pedoman Pendidikan UM. Malang : Universitas Negeri Malang

Undang-undang Republik Indonesia Nomor 20 Tahun 2003 tentang Sistem Pendidikan Nasional. 2003. Jakarta: Presiden Republik Indonesia

Winarno, M. E. (2011). Metodologi Penelitian dalam Pendidikan Jasmani. Malang: Media Cakrawala Utama Press.

Woodille, Gary. (2011). Mobile Learning. US; The Mc Graww-Hill Companies. 